\title{
Economic dimensions of armed groups: profiling the financing, costs, and agendas and their implications for mediated engagements
}

\section{Achim Wennmann*}

Dr. Achim Wennmann is Researcher at the Centre on Conflict, Development and Peacebuilding (CCDP) of the Graduate Institute of International and Development

\author{
Studies in Geneva.
}

\begin{abstract}
This article introduces the various economic dimensions of armed groups and explores the implications of their engagement through mediation and dialogue. It looks specifically at the financing, operational costs, and economic agendas of armed groups and brings together examples from Angola, Kosovo, Sudan, Colombia, and other places. It emphasizes that information about available financing and operational costs is critical for assessing the financial and operational strength of an armed group. It also highlights the need to understand armed groups in the broader context of their evolution and the changes that organizational and territorial expansions require with
\end{abstract}

* This article provided a welcome opportunity for the author to synthesize various work streams on the economic dimensions of armed conflict into a single text focusing on armed groups. It draws specifically on Achim Wennmann, The Political Economy of Peacemaking, Routledge, London, 2011, and Achim Wennmann, 'Conflict financing and the recurrence of intra-state armed conflict', $\mathrm{PhD}$ thesis, University of Geneva and Graduate Institute of International Studies, Geneva, 2007. Other publications of the author on which the article draws are included in the relevant footnotes. The author thanks Jennifer Hazen for comments. 
regards to financing strategies. Overall, the economic dimensions of armed groups should be approached with an open mind so that issues such as financing, costs, and economic agendas can be perceived as opportunities, and not necessarily as a problem for peace.

The economic dimensions of armed conflict have been much written about, but not always understood in their full complexity. Be they natural resources, from coltan to timber, or the greedy economic agendas of 'warlords', economic dimensions have been the subject of United Nations proceedings, advocacy initiatives, and scholarly investigation. As they make sense of the financing, costs, and agendas of armed groups, policy, research, and activist communities face similar problems: reliable information on the economic dimensions is hard to come by in messy civil war contexts. The results are broad estimates, a tendency towards inflating the little evidence there is, and significant room for interpretation based on 'best available information' in the public domain.

This absence of reliable sources is part of the limitation but also the fascination of studying the economic dimensions of armed conflicts and the armed groups that fight them. Economic dimensions are important in understanding conflict dynamics and can also provide insights for mediators as they prepare mediated engagements. What is more, economic factors can structure the context in which armed groups fight, mobilize support, and build relationships with local populations. This article focuses on the economic dimensions of 'armed groups', as opposed to 'armed conflict'. Fragments of information on the economic dimension of armed groups are often hidden within the literature on the political economy of armed conflict. I therefore propose to bring these fragments together and present an analysis of the economic dimensions of armed groups. The article profiles the financing, mobilization costs and economic agendas of armed groups, and explores what these dimensions imply for the engagement of armed groups through mediation and dialogue.

The article unpacks the economic dimensions of armed groups along four paths: first, it analyses the current state of knowledge about the financing of armed groups. Second, it investigates the mobilization costs of armed groups. These costs capture the funding needed to equip a certain number of people and ensure that they can engage in fighting for a certain amount of time. As I will show, contrasting the mobilization costs with the available funding is critical analytically: knowing how much money an armed group has does not yet allow any conclusions about how well it can translate these resources into battle or organizational success. Other factors for the calculation include the power of the adversary, and the creativity of leadership. Third, the article looks at the way in which armed groups transform over time. In some cases such as the Fuerzas Armadas Revolucionarias Colombianas (FARC), the Liberation Tigers of Tamil Eelam (LTTE), the Sudan People's Liberation Movement/Army (SPLM/A), or the Communist Party of Nepal-Maoist $(\mathrm{CPN}-\mathrm{M})$, the controlled territories became 'de facto' states where these groups 
wielded some level of empirical sovereignty. ${ }^{1}$ The fourth part links economic agendas of armed groups to mediation and dialogue processes. It inquires how economic dimensions can become an opportunity for a forward-looking transformation of armed groups while strengthening their commitment to participate in a political process. Overall, this article argues that we need to broaden our study of the economic dimensions of armed groups so that we can identify and seize new opportunities for peace-making.

\section{The financing of armed groups}

About a decade ago, the issue of conflict financing was catapulted to international attention because a number of African armed groups were financing themselves through natural resources. The term 'conflict diamonds' became a symbolic reference for describing the link between greedy warlords, war crimes, and illicit commerce - all themes that have triggered significant political, advocacy, and scholarly efforts, and have also inspired a series of blockbuster movies. While diplomatic and advocacy efforts focused on United Nations responses to Angola, the Democratic Republic of the Congo (DRC), Liberia, and Sierra Leone, there was a separate - but connected - evolution of scholarly debate about the role of natural resources in armed conflict. Some exposed an inevitable causal link, while others invited a case-by-case and contextual analysis. ${ }^{2}$ The intense political, advocacy, and scholarly attention marked the early efforts on conflict financing, and the relationship between natural resources and armed conflict. Over time, perspectives widened and stark claims were qualified, while placing analyses in their historical and local context. The debate whether 'greed' or 'grievance' would cause armed conflict was laid to rest by describing that they were really just 'shades of the same problem'. ${ }^{3}$

1 Empirical sovereignty is associated with the criteria of statehood identified in Article 1 of the 1933 Montevideo Convention on Rights and Duties of States: a permanent population, a defined territory, a government, and the capacity to enter into relations with other state. While de facto states may have empirical aspects of sovereignty, they lack juridical sovereignty associated with international recognition because their territory is already part of an existing and recognized state. See Scott Pegg, International Society and the De Facto State, Ashgate, Aldershot, 1989, p. 26. Dov Lynch, Engaging Eurasia's Separatist States: Unresolved Conflicts and the De Facto States, United States Institute of Peace Press, Washington DC, 2004, p. 16.

2 Paul Collier and Anke Hoeffler, 'On the economic causes of civil war', in Oxford Economic Papers, Vol. 50, No. 4, 1998, pp. 563-573; Mats Berdal and David M. Malone (eds), Greed and Grievance: Economic Agendas in Civil Wars, Lynne Rienner, Boulder, CO, 2000; Karen Ballentine and Jake Sherman (eds), The Political Economy of Armed Conflict: Beyond Greed and Grievance, Lynne Rienner, Boulder, CO, 2003; Paul Collier and Nicholas Sambanis (eds), Understanding Civil War: Evidence and Analysis, Volume 1: Africa, The World Bank, Washington DC, 2005; Cynthia J. Arnson and I. William Zartman (eds), Rethinking the Economics of War: The Intersection of Need, Creed, and Greed, Woodrow Wilson Center Press, Washington, DC, 2005.

3 Ian Bannon, 'Preface', in P. Collier and N. Sambanis, above note 2, p. xi. 


\section{A historical perspective on financing war}

The recent efforts described above are not to downplay the long historical record of scholarship on the matter, as well as the existence of an entire discipline of defence economics, even though the focus is on state armies and inter-state wars. ${ }^{4}$ Common sources of war financing described in the historical work included booty, indemnities, taxes, loans, credits, and the reduction of consumption. Living off the land of the conquered or an area of transit was used to nourish and supply armies until the beginning of the twentieth century, with often significant economic and humanitarian consequences for local populations. ${ }^{5}$ Such 'living off the land' does still take place in some conflict situations today, even though some modern armies have developed significant logistical capabilities to supply troops over great distances.

The financing of war efforts has also been associated with the evolution of the state in Europe, where various rulers set up intricate extraction systems to acquire the resources for state-making, war-making and protection. ${ }^{6}$ Those states that were able to organize their extraction successfully - and spent it wisely-persisted; others - such as the kingdom of Burgundy, which did not - disappeared. ${ }^{7}$ In the scholarly literature on political economy, these types of financing relate to the concepts of the 'roving' and 'stationary' bandit. ${ }^{8}$

The extractive character of state armies stands in contrast to the doctrine of guerrilla warfare, which stresses the symbiotic relationship with local communities. The argument of symbiosis was part of Mao Tse Tung's and Ernesto Che Guevara's work on closed insurgency economies. ${ }^{9}$ These economic strategies, however, have their own humanitarian consequences, as local communities increase their risk of being targeted by counter-insurgency campaigns. Relying only on symbiosis was also insufficient for mobilizing resources to maintain guerrilla activities, which explains why insurgents need to be highly mobile, and move around from community to community while ensuring external support. ${ }^{10}$

War in all ages presented such an enormous strain on the resources of states and populations that it fostered financial innovation to the extent that

4 Charles H. Anderton and John R. Carter, Principles of Conflict Economics: A Primer for Social Scientists, Cambridge University Press, Cambridge, 2009; Ron Smith, Military Economics: The Interaction of Power and Money, Palgrave Macmillan, Basingstoke, 2011.

5 Michael Howard, War in European History, Oxford University Press, Oxford, 1976, pp. 85, 98.

6 Charles Tilly, Coercion, Capital and European States, AD 990-1992, Blackwell, Oxford, 1992, pp. 74-76, 96.

7 John Keegan, A History of Warfare, Pimlico, London, 1993, p. 329.

8 The 'roving bandit' is a predator who loots while sweeping through various territories to accumulate personal riches; the 'stationary bandit' stays in one territory and provides protection to some parts of the population in return for local investments that increase the bandit's wealth. See Mancur Olson, 'Dictatorship, democracy, and development', in American Political Science Review, Vol. 87, No. 3, 1993, p. 568.

9 Jean-Christophe Rufin, 'Les économies des guerres dans les conflits internes', in François Jean and Jean-Christophe Rufin (eds), Économie des guerres civiles, Hachette, Paris, 1996, pp. 21-23. Ibid. 
'financial history cannot escape dealing with war'. ${ }^{11}$ For instance, between 1515 and 1565, the Habsburg Netherlands were the first to mobilize future revenue for present needs. Given that expenditure for war came in surges, the ability to incur debts made it possible to generate large sums of money quickly. ${ }^{12}$ Since then, the relationship between debt and taxes - and whether war should be financed by the present generation through taxation or by future generations through debt - has remained a central political debate surrounding every major armed conflict. In recent years, such debates have occurred in the context of the wars in Afghanistan, Iraq, and Libya. History also suggests that the state's ability to incur debt and raise taxes makes it one of the most effective strategies to finance armed conflict.

This historical perspective on conflict financing is instructive in the sense that those individuals or groups wanting to organize an armed conflict must overcome some basic mobilization challenges relating to recruitment, control, and financing. ${ }^{13}$ These challenges are similar for state armies, non-state armed groups, and transnational terrorist networks. In a sense, systematic military campaigns must be organized in difficult contexts and environments, which in turn requires a high degree of entrepreneurial skill, street smarts and long working hours from armed groups. In most cases, states have the critical advantage over non-state armed groups of a pre-existing treasury and bureaucracy, as well as the capacity to mobilize future revenue for present needs.

\section{Financing methods of armed groups}

Armed groups use a wide variety of financing methods to sustain their military activities as well as the combatants that make up the armed groups. Strategies used by armed groups include, for example, bank robbery, foreign government support, revenue from natural resources, kidnapping, diaspora remittances, and taxes. ${ }^{14}$ The kinds of methods used to finance armed groups depend on the opportunities for money-making in the specific territories that an armed group controls, the geo-strategic significance of this territory, and the international political context that shapes the conflict.

For instance, in Nigeria the presence of oil defines incentives for oil theft, kidnapping of oil workers, and support from frustrated communities. In contrast, the political nature of the Israel/Palestine conflict invites often contested foreign government support; while armed groups in Indonesia, Somalia, and Sri Lanka could draw on diaspora remittances and taxation of local communities. Financing

11 Charles P. Kindleberger, A Financial History of Western Europe, Oxford University Press, Oxford, 1993, p. 7.

12 James D. Tracy, A Financial Revolution in the Habsburg Netherlands: Renten and Renteniers in the County of Holland, 1515-1565, University of California Press, Berkeley, 1985, pp. 218, 221.

13 Jeremy Weinstein, Inside Rebellion: The Politics of Insurgent Violence, Cambridge University Press, Cambridge, 2007, pp. 20-21.

14 For an overview of financing methods, see Achim Wennmann, 'The political economy of conflict financing: a comprehensive approach beyond natural resources', in Global Governance, Vol. 13, No. 3, 2007, pp. 431-436. 
efforts also vary between the odd bank robbery of smaller armed groups, and the intricate, state-like fundraising or transfer systems of larger ones.

How well armed groups are able to translate financing into successfully reaching their objective depends on the quality of leadership, as well as the international alliances and support that they can count on. There is also evidence that there is a relationship between the initial endowments of armed groups and the use of armed violence in recruiting practices. Resource-rich armed groups recruit opportunity-minded soldiers with coercive strategies. In contrast, resource-poor groups recruit more activist-minded soldiers with participatory strategies. ${ }^{15}$

So far, research on the financing of armed groups has mainly relied on case studies of particular groups, and efforts to establish comparative empirical evidence are in their infancy. ${ }^{16}$ While current efforts are good at listing strategies used by specific armed groups, a next step would be to identify which methods are used at what point in time of a conflict, the amount of revenues fundraised, and how - if at all - the available revenue has an impact on the dynamics of the conflict. Such information is of course difficult to generate, but systematic efforts to collect the best available information about the financing of armed groups may be able to provide new insights into the ways that armed groups innovate and transform.

\section{Examples of financing methods and means}

One of the best-documented financing infrastructures is that of the União Nacional para a Independência Total de Angola (UNITA). For the supply logistics and diamonds trade, a number of transport agents acted autonomously or as government agents within larger networks based on the relationships between UNITA and the Governments of Togo, Burkina Faso, and Zaire. ${ }^{17}$ UNITA also maintained representatives abroad who were known to control bank accounts in France, Portugal, Switzerland, Ireland, Belgium, Côte d'Ivoire, and the United Kingdom, as well as in offshore centres, which generated returns from capital investments. ${ }^{18}$ Towards the end of the conflict, Jonas Savimbi, UNITA's leader, also held a significant stockpile of diamonds. At this point diamonds became the actual

15 J. Weinstein, above note 13, pp. 20-21, 171-172, 328-329.

16 An exception is the Database of Transnational and Non-state Armed Groups that gathers information about fifty armed groups, including on financing strategies. It was established by the Graduate Institute of International and Development Studies in Geneva and the Program on Humanitarian Policy and Conflict Research at Harvard University. The database can be accessed on request by contacting the Centre on Conflict, Development and Peacebuilding (CCDP) of the Graduate Institute (ccdp@ graduateinstitute.ch).

17 Small Arms Survey, Small Arms Survey 2001: Profiling the Problem, Oxford University Press, Oxford, 2001, p. 117.

18 United Nations Security Council (UNSC), Additional Report of the Monitoring Mechanism on Sanctions against UNITA, UN Doc. S/2002/486, 26 April 2002, para. 199. UNSC, Supplementary Report of the Monitoring Mechanism on Sanctions Against UNITA, UN Doc. S/2001/966, 12 October 2001, paras. 234-247. 
currency with which UNITA paid for arms, transport services, and political patronage. ${ }^{19}$

Kosovo also had an intricate funding system that supplied the resources for parallel government and society institutions between 1989 and 1995. The starting point for the creation of diaspora financing was the knowledge of an estimated USD 3 billion of savings held by the Kosovo Albanian diaspora in their host countries. ${ }^{20}$ Based on these estimates, it was decided in the early 1990s that a $3 \%$ voluntary tax of net income was an acceptable contribution to the survival of Kosovo. The threshold of 3\% was set as low as possible but encompassed everyone, as with fiscal politics. The Government in Exile also solicited legal experts to ensure compliance to the laws of the countries in which transactions took place. Not breaking any of the national laws of the countries hosting the Kosovo Albanian diaspora community was paramount to ensuring confidence in the system, and to preventing subversion by the authorities of Yugoslavia. The core problem was transferring the money from Switzerland or Germany to Kosovo. While money could be wired to accounts in Albania, transfers into Kosovo mainly occurred through cash couriers. When the Kosovo Liberation Army (KLA) wrested power from the Government in Exile in 1997 and advocated a militarized resistance strategy, it took over the established structure while shifting from voluntary to enforced contributions over time. ${ }^{21}$

\section{The importance of a careful analysis and of context}

The Angola and Kosovo examples illustrate how carefully one has to analyse issues related to conflict financing. Broad, general conclusions and high estimates of the financing available to armed groups should always be approached with a degree of caution and never adopted without understanding the bases from which they have been inferred. The financing of armed groups involves a huge amount of creativity and persistence on the part of their leaders, especially if funding mechanisms have to be covert to avoid being detected by domestic or international law enforcement agencies. Conflict financing is also inherently dynamic, not static. Strategies must be quickly adapted in the face of external threats or to explore new opportunities as they arise. The failure to do so may mean the end of an armed group.

Careful analysis is also required when conflict financing is linked to natural resources such as diamonds, drugs, or timber. ${ }^{22}$ This can consist of actual

19 Christian Dietrich, 'UNITA's diamond mining and exporting capacity', in Jakkie Cilliers and Christian Dietrich (eds), Angola's War Economy: The Role of Oil and Diamonds, Institute for Security Studies, Pretoria, 2000, pp. 275-294.

20 This figure has been based on revenue estimates of Kosovo Albanians living abroad calculated by the Government of Kosovo in Exile.

21 Interview with Naip Zeka, Former Administrator of Financing the Parallel System of Governance in Kosovo, Pristina, 28 July 2005; interview with Isa Mustafa, Former Minister of Finance in Exile, Pristina, 27 July 2005.

22 A. Wennmann, above note 14. 
involvement in the extraction or trade of the resource, mere taxation of such extraction or trade, or use of the resource as barter against weapons or war-related services. As the example of Savimbi illustrated above, natural resources are also used to store value, given the difficulty of storing stashes (or pallets) of bills in many conflict areas. Furthermore, natural resources differ in their role in conflict financing depending on their innate or geographical characteristics. For example, 'concentrated' resources - such as oil or minerals - require considerable investments and partnerships for exploration. They are therefore more likely to be a financing strategy for state actors, rather that smaller armed groups. The latter may be involved in oil bunkering, but this is distinct from really managing an entire exploration process. In contrast, 'diffuse' resources - such as alluvial diamonds are much more accessible for armed groups owing to their lootable character. They also require much smaller capital investments for their exploration owing to their occurrence on the surface or in riverbeds.

It is also important to understand the context of many conflict zones, which often defines the ease or difficulty of mobilizing financing. Such a context can be a territory controlled by an armed group that is beyond the reach of government control or oversight. Especially lucrative are porous border areas, such as the African Great Lakes region or the Laos-Myanmar-Thailand triangle, which allow for the operation or taxation of cross-border trade. ${ }^{23}$ Moreover, depending on the economic or strategic value of that territory, an armed group can have a fairly large pool of willing collaborators - including both state sponsors and different types of commercial actors. These facilitate financing by providing access to international arms, commodity, and financial markets, while advancing particular political and business interests and pocketing a highrisk premium, as the example of UNITA shows. ${ }^{24}$ This win-win situation can foster a vested interest in maintaining an armed conflict and the conditions that it creates.

\section{The mobilization costs of armed groups}

So far, we have just covered one side of the equation of the financing of armed groups: finding the money to pay for the group. The other side is supplied by the mobilization costs: the cost of recruiting and equipping a certain number of belligerents, and maintaining them during weeks, or years, of combat.

23 Mark Duffield, 'Globalization, transborder trade, and war economies', in M. Berdal and D. M. Malone, above note 2, pp. 69-90. See also Alexander Ramsbotham and I. William Zartman (eds), Accord, Paix Sans Frontières: Building Peace Across Borders, Vol. 22, Conciliation Resources, London, 2011.

24 Peter W. Singer, 'Corporate warriors: the rise of the privatized military industry and its ramifications for international security', in International Security, Vol. 26, No. 3, 2001, pp. 186-220; David Shearer, Private Armies and Military Intervention, International Institute for Strategic Studies, London, 1998. 


\section{Calculating mobilization costs}

Overall, one can distinguish between the cost to start and the cost to maintain an armed group. Start-up costs mean paying for a battle-ready military force including factors such as weapons, ammunition and other equipment, the logistics to deploy to the battlefield, and - in the case of larger formations - an administrative structure. Maintenance costs capture the cost of sustaining combat, including paying and replacing soldiers and supplying and replacing weapons, ammunition, and other materiel. The main difference between these two dimensions is that the costs to start a conflict are relatively predictable while the cost to maintain a conflict are dynamic depending on the conflict intensity and duration, the rate of replacement for soldiers and materiel, and the inflation of prices for weapons, ammunition, and other items during armed conflict. In this way, the cost to maintain armed conflict is disproportionately higher - and less predictable - than the cost to start a conflict. In Kosovo, for example, prices for AK-47s increased 7.5 times between spring 1997 and spring 1998, and peaked at 16.25 times in autumn $1998 .{ }^{25}$

Recent advances in small arms research have made it possible to develop an estimation tool for mobilization costs. ${ }^{26}$ This tool relies on four data points - the cost of weapons, the cost of ammunition, the income per soldier, and the number of soldiers - to perform an estimation of a lowest threshold for the start-up and annual maintenance costs of an armed group. A cost-estimate example using this tool suggests that start-up costs range from USD 67,500 to USD 450,000 per 1,000 soldiers. The maintenance cost of an armed conflict of various degrees of intensity is in the region of USD 2-35 million per 1,000 soldiers per year. ${ }^{27}$ This cost-estimate example also shows that ammunition is one of the key cost drivers during armed conflict. A three-fold increase in ammunition prices during armed conflict increases the total cost of conflict by about one-third. What is more, paying soldiers salaries is an important fixed cost that raises the barrier to entry. ${ }^{28}$

These figures underline the fact that conflict financing is not only about the amount of funds available but also about whether these funds can pay for a particular type of military strategy. Whether an armed group decides to use guerrilla tactics or to scale up investments into a conventional capability has significant cost implications. In order to apply a military strategy effectively, armed

25 Black market prices for an AK-47 in Albania increased from USD 40 to USD 300 between spring 1997 and spring 1998, peaking at USD 650 in autumn 1998 before decreasing to USD 125 a year later when the Kosovo conflict terminated. Small Arms Survey, Small Arms Survey 2002: Counting the Human Cost, Oxford University Press, Oxford, 2002, p. 69.

26 The estimation tool is fully developed in Achim Wennmann 'Grasping the financing and mobilization cost of armed groups: a new perspective on conflict dynamics’, in Contemporary Security Policy, Vol. 30, No. 2, 2009, pp. 265-280.

27 The differences in these cost estimates are based on the use of different price ranges. Weapons prices range between USD 40 and USD 250, ammunition prices between USD 0.05 and USD 0.5, and income per soldier between USD 2,000 and USD 10,000 per year. See ibid., pp. 267-271. 
groups must overcome a barrier to entry into an armed conflict and have the money to cover the cost of the military strategy that they decide on to achieve their objectives. Considering the financing and costs of armed groups together proves the assumption wrong that 'rebel groups more than cover their costs during the conflict $^{29}$ and underlines that 'ten thousand dollars and a satellite phone' - as Laurent Kabila in the DRC confessed ${ }^{30}$ - are not necessarily sufficient to organize an armed conflict that goes beyond uncoordinated raids.

\section{Implications for development and humanitarian organizations}

Knowledge about these barriers to entry and cost of competition can be particularly useful for development or humanitarian organizations. In many contexts, absolute material scarcity makes humanitarian goods or development assistance extremely valuable. Through robbery of the aid or material (cars, office equipment), or service charges for the distribution of aid, many organizations have faced challenges that they contributed to the financing of armed groups, and to the prolongation of armed conflict. ${ }^{31}$

Development and humanitarian organizations have taken these challenges extremely seriously and have developed significant measures to avoid the misappropriation of aid. These efforts have, for example, included the adoption of do-no-harm or conflict-sensitivity frameworks by major development organizations. The International Committee of the Red Cross, for instance, has taken measures to prevent misappropriation through a series of operational changes, such as maintaining close relationships to recipient communities, and practising a zero-tolerance policy towards any staff members found to have stolen or misappropriated relief goods. ${ }^{32}$

A better understanding of the mobilization cost of a specific armed group could help inform these measures in at least two ways. First, it could demonstrate that the amounts of misappropriated aid or stolen material are likely to be insufficient to cover major war-related expenses, and that they would be only a minor source of funding - if not merely related to personal enrichment of specific commanders or soldiers. In this case, knowledge about mobilization costs would help determine the relative importance of stolen or misappropriated aid in financing an armed group. Second, if aid is potentially found to contribute to the funding of an armed group in a specific context, better knowledge about

29 Paul Collier and Anke Hoeffler, 'Greed and grievance in civil war', in Oxford Economic Papers, Vol. 56, No. 4, 2004, p. 564.

30 See Aidan Hartley, 'The art of darkness', in The Spectator, 27 January 2001, available at: http:// findarticles.com/p/articles/mi_qa3724/is_200101/ai_n8941934/(last visited 30 September 2011).

31 Mary B. Anderson, Do No Harm: How Aid Can Support Peace - or War, Lynne Rienner, Boulder, CO, 1999.

32 ICRC, 'Amid war and crime: humanitarian aid in high-risk environments - interview with Dominik Stillhart', 9 April 2010, available at: http://www.icrc.org/eng/resources/documents/interview/hum-aidin-high-risk-env-interview-090410.htm (last visited 15 September 2011). 
mobilization costs can help structure the operational planning of development and humanitarian programmes.

\section{Effects on conflict dynamics}

The interplay between available funding and mobilization costs provides a new perspective on conflict dynamics. In Angola, for example, UNITA's revenue declined from around USD 500 million in 1997 to USD 80 million in 2000. This drop resulted from government advances into diamond areas and was accompanied by increasing mobilization costs due to multilateral sanctions and longer supply lines. ${ }^{33}$ In consequence, it became too expensive and complicated to maintain UNITA's conventional military capability. As a result, UNITA reverted to guerrilla tactics that did not rely on tanks or other conventional military equipment. ${ }^{34}$ In the long term, UNITA was unable to diversify revenue sources to pay for another conventional military build-up and match the escalation driven by government forces in 2000. The territorial advances of the government's oilfinanced military undermined UNITA's centralized structure and heralded its downfall. ${ }^{35}$

The effect of the revenue/cost interplay on conflict dynamics is also illustrated in Kosovo. The favourable conditions for diaspora financing explained above provided the KLA with sufficient revenue to start the conflict; but it was insufficient to maintain it given the strength of the conventional military capability of Serbia. In consequence, the KLA faced significant financial and military strains at the end of 1998 and was - literally - saved by the North Atlantic Treaty Organization (NATO). NATO escalated the conflict at a cost of an estimated USD 4 billion for air operations only. ${ }^{36}$ In this case, internationalizing the conflict and finding an external party to pay the bill was an effective strategy towards winning the war.

\section{The effectiveness of financing strategies}

The interplay between available funding and costs also provides a new insight into what is an 'effective' source of conflict financing. Effectiveness is understood as the financing method having the capacity to generate enough revenue to pay for the start-up and maintenance of a specific military strategy (i.e. insurgency, conventional land war, air raids, sieges, etc.). Angola is again a case in point: oil provided

33 Alex Vines, 'Angola: forty years of war', in Peter Batchelor and Kees Kingma (eds), Demilitarisation and Peace-Building in Southern Africa-Volume II: National and Regional Experiences, Ashgate, Aldershot, 2004, p. 87.

34 Assis Malaquias, 'Angola: how to lose a guerrilla war', in Morten Bøås and Kevin C. Dunn (eds), African Guerrillas: Raging Against the Machine, Lynne Rienner, Boulder, CO, 2007, pp. 212-215.

35 Achim Wennmann, 'Conflict financing and the recurrence of intra-state armed conflict', $\mathrm{PhD}$ thesis, University of Geneva and Graduate Institute of International Studies, Geneva, 2007, pp. 203-204.

36 Taylor B. Seybolt, 'Major armed conflicts', in Stockholm International Peace Research Institute Yearbook 2000, Oxford University Press, Oxford, 2000, p. 32. 
government forces with a strategic advantage because it generated more revenue than diamonds. Its revenue base was also less vulnerable to attack, owing to its offshore location. In contrast, UNITA was unable to establish control over the capital and the state because diamonds did not generate enough revenue to escalate the conflict and match the military prowess of the government.

One can differentiate between three levels of financing in terms of effectiveness. On the first level are resources that are easy to centralize, and generate a high value and immediate revenue stream. These are essentially characteristics associated with oil, diamonds, drugs, and third-party direct financial assistance, and they are important for the start-up or escalation phase when financial requirements are highest. On the second level are resources that provide constant revenue over time. These include taxation, parallel economies, and diaspora financing and are useful to cover maintenance costs. On the third level are resources deriving from humanitarian assistance, contributions of individuals, kidnapping, asset transfers from civilians, landing fees, and revenue from portfolio investments. These are less effective strategies of conflict financing because on their own they cannot finance an armed conflict even though they can be important in motivating commanders and troops.

\section{Conflict financing and peace processes}

Finally, the financial situation of an armed group can provide information about their attitude towards an evolving peace process. ${ }^{37}$ If armed groups face revenue constraints, a peace process can relate to a change in tactics because armed violence has become too expensive to maintain. Engaging in a peace process can also mean gaining a tactical pause to regroup, and to find new money in order to continue fighting at some point in the future. If armed groups are relatively revenueabundant, they can use peace processes to diversify their military strategies by opening a political front, or as a means to realize other political agendas that are not necessarily related to the conflict. Of course, no matter what the financial situation, all parties can engage as a result of a strategically informed choice that armed violence no longer fulfils strategic objectives.

\section{The evolution of conflict economies}

An additional element in understanding the economic dimensions of armed groups is to place the financing and mobilization costs within the context of conflict economies. Such a perspective focuses on the transformation of armed groups, and how that relates to the evolution of conflict economies. 


\section{Types of conflict economy}

The understanding of this evolution has rested on the interaction of the type of conflict economy (predation, parasite, extraction) and the military strategy of armed groups (contention, expansion, control). ${ }^{38}$ The different categories in this evolution include:

- Predation-Contention: the conflict economy is predatory and the military strategy is based on contention with government forces. Armed groups operate in areas formally under state control and in order to destabilize the state and raise funds. They conduct hit-and-run attacks such as killings, kidnappings, burglaries, or bank robberies. At this stage, expenditure requirements are small, as the armed group itself is small and operations are relatively small-scale.

- Parasite-Expansion: as armed groups grow in size and territorial reach, the conflict economy becomes increasingly parasitical. Operations take place in a particular geographic area in which the group expands control. The military strategy shifts from hit-and-run attacks to low-intensity warfare and to economic strategies to weaken the government. As the formal economy declines and the government loses fiscal revenues, an armed group captures a bigger share of the shadow economy and is strengthened through additional revenues.

- Extraction-Territorial Control: insurgents establish control over an area from which the state is excluded. In this area, an armed group becomes the de facto government and runs social services, arbitration, and a taxation system. This last generates funding to continue military activities. These areas can ultimately evolve into a 'de facto state' in which an armed group establishes control over territory and population and creates institutions.

There are certainly wider variations within and between these categories, but armed groups that broadly fit in this evolution include the Sendero Luminoso in Peru, the National People's Army in the Philippines, the Bougainville rebels in Papua New Guinea, the Khmer Rouge in Cambodia, the Tamil Tigers in Sri Lanka, UNITA in Angola, the CPN-M in Nepal and the FARC in Colombia. ${ }^{39}$ The evolution also implies that there are different financing strategies for different phases as financial requirements increase.

The FARC is an instructive example of a transformed conflict economy, especially the group's relationship to drugs. While initially only taxing the trade, by the late 1980s the FARC provided security to local communities in the face of an influx of foreign drug traffickers and profiteers. By providing the conditions that

38 R. Thomas Naylor, Wages of Crime: Black Markets, Illegal Finance, and the Underworld Economy, Cornell University Press, Ithaca, NY, 2002, pp. 45-47, 53-54. Achim Wennmann, 'Conflict economies', in Vincent Chetail (ed.), Post-Conflict Peacebuilding: A Lexicon, Oxford University Press, Oxford, 2009, pp. 80-81; James Cockayne, 'Chapter ten: crime, corruption and violent economies', in Mats Berdal and Achim Wennmann (eds), Ending Wars, Consolidating Peace: Economic Dimensions, Institute for International and Strategic Studies, Adelphi Series, Vol. 50, Nos. 412-413, Routledge, London, 2010, pp. 193-198. The list of categories given here is drawn from these studies.

39 R. T. Naylor, above note 38, pp. 45-47, 53-54. 
made a livelihood for local coca farmers possible, the FARC could legitimize itself in the eyes of the local population as a de facto state. However, by the end of the 1990s, some leading figures became involved in the drug business, thus undermining its image as a peasant rebellion. While the FARC stayed a movement with political objectives and strategies, its association to drug trafficking complicated peace talks and made the government less willing to give it any form of legitimacy or recognition. Ultimately, the FARC's drug involvement made the conflict a criminal issue that called for a law enforcement approach. ${ }^{40}$

\section{Understanding conflict economies}

Understanding the evolution of conflict economies has implications for the way in which we understand armed groups in conflict zones. Those actors that evolve towards a quasi-state build loyalties with local populations by offering job opportunities and protection, as well as some level of local stability. A charismatic leader can increase the level of loyalty at the same time as the cost of rebellion against or defection from the group. ${ }^{41}$ Other groups such as the Lord's Resistance Army in Uganda or the Revolutionary United Front in Liberia prey on local populations at the predation-contention level.

What is more, non-state armed groups do not necessarily act against the state but merely focus on keeping central authorities at bay. ${ }^{42}$ The presence of armed groups may therefore only imply that there is no presence of the state that would make any meaningful difference for the people. ${ }^{43}$ In these situations 'the performance of traditional state functions ... has been assumed by different gangs, splintering countries into sections of autonomy'. ${ }^{44}$

Understanding these local political and economic dynamics is a crucial element for engaging with armed groups, especially for a forward-looking peace mediation strategy. A context-sensitive perspective on war economies and governance arrangements is an important component of exploring what visions for the future can find traction with armed groups and local populations. Economies in times of war are never just interruptions of what would otherwise be a linear path of economic or political development. ${ }^{45}$ Economies and societies experience significant transformations in times of war, and it is important not to lament that 'nothing' is there, or that all that is there is 'bad'. Rather, the task is to recognize the

40 Claire Metelits, Inside Insurgency: Violence, Civilians, and Revolutionary Group Behaviour, New York University Press, New York, 2010, pp. 100-102.

41 Kimberly Zisk Marten, 'Warlordism in a comparative perspective', in International Security, Vol. 31, No. 3, 2007, pp. 58 and 72.

42 Philippe Le Billon, The political economy of war: what relief agencies need to know, Humanitarian Practice Network, Paper No. 33, Overseas Development Institute, London, 2000, p. 4.

43 William Reno, 'Bottom-up statebuilding?', in Charles T. Call with Vanessa Wyeth (eds), Building States to Build Peace, Lynne Rienner, Boulder, CO, 2008, p. 143.

44 John Rapley, 'The new Middle Ages', in Foreign Affairs, Vol. 85, No. 3, 2006, p. 95.

45 Christopher Cramer, Civil War is Not a Stupid Thing: Accounting for Violence in Developing Countries, Hurst and Company Publishers, London, 2006, p. 197. 
strengths of conflict economies - the social capital, the resilience of people, and the levels of existing investments - while addressing issues such as rapacious natural resource exploitation, forced labour, or drug trafficking through negotiated transformation processes. The positive unintended consequences of economic transformations during armed conflict are a much overlooked opportunity to strengthen war-to-peace transitions.

\section{Economic agendas and the engagement of armed groups}

There are various scholarly perspectives that locate the motivation for armed violence in grievances, rights, and greed, with the associated stakes of basic needs, identity, and resources. ${ }^{46}$ The underlying assumption behind these approaches is that armed violence is a purposefully applied instrument to achieve specific objectives. This notion contrasts with the view that armed violence is an innate human attribute, which has been central to some of the work on ethnic conflicts. At the political level, for example, armed violence can be used to check or intimidate opposition groups or specific constituencies. At the economic level, armed groups use violence to control state resources, companies, or labour. Violence can also be part of a struggle to gain or maintain access to state resources, or to protect monopolistic control over economic opportunities. At the psychological level, armed violence has been associated with status, personal enrichment, impunity, excitement, and self-aggrandizement. ${ }^{47}$ While violence is never caused by any single attribute alone, the study of economic agendas of armed groups has been located within the political, economic, and psychological functions of armed violence.

\section{Understanding economic functions of violence}

In terms of economic agendas in particular, economic functions of violence imply that violence is less used to achieve political goals than the Clauswitzean dictum 'war is politics by other means' would assume. Instead, it is used to further economic interests leading to the perpetuation of armed violence as a means to benefit from the conditions that such a conflict generates. In this context, 'war is not simply a breakdown of a particular system, but a way of creating an alternative system of profit, power and even protection' ${ }^{48}$

Economic agendas thus have implications for the engagement of armed groups in mediation or dialogue processes. First, belligerents may be less inclined to respond positively to engagement if violence has economic functions. Such violence offers belligerents a way of life that would be impossible for them to achieve in peacetime. This so-called 'Kalashnikov lifestyle' translates into

46 I. W. Zartman, 'Need, creed, and greed in intrastate conflict', in C. J. Arnson and I. W. Zartman, above note 3 , p. 262.

47 David Keen, The Economic Functions of Civil War, International Institute for Strategic Studies, Adelphi Paper No. 320, Oxford University Press, Oxford, 1998, p. 12.

48 Ibid., p. 11. 
commercial and political networks controlled by strongmen. In this way, armed violence is associated by many young adults with a strategy of socio-economic mobility, which provides a strong motivation to sign up to fight. ${ }^{49}$ Since armed violence is profitable and part of a livelihood strategy, belligerents are less susceptible to incentives associated with a ceasefire unless it offers disproportionately higher rewards than the continuation of fighting. These rewards are often difficult to communicate to the fighters - some starting as child soldiers - who have known little else than making money at gunpoint. For them, life without a weapon means a lower social status and less money. A ceasefire would threaten the lifestyle they know.

\section{Some considerations on engaging armed groups and the example of Sudan}

The starting point for the engagement of belligerents is therefore not a mutually hurting stalemate, but a mutually profitable stalemate..$^{50}$ The former has been described as an appropriate moment to table a proposal for a negotiated exit out of the conflict because none of the parties is coming any closer to achieving its goal. The parties realize that the cost of continuing the conflict exceeds the benefits that they are likely to obtain from it. ${ }^{51}$ However, experiences of protracted conflicts such as Angola, the DRC, and Sri Lanka suggest that sporadically recurring armed violence or full-scale military manoeuvres serve the purpose of keeping the conflict alive, which in turn ensures economic benefits for the warring parties. These economically motivated stalemates, however, do not hurt the belligerents (while of course civilian populations are clearly affected by the consequences of the stalemate). As a result, the leadership or factions that have been involved in conflict economies are less inclined to engage in a mediation process; or to fully commit if they do decide to engage. Asking for a ceasefire in these circumstances means that the belligerent parties would have to accept an end to hostilities - thereby undermining their financing and profits - without any alternative economic prospects in the future. This is why it is so important to link ceasefires to forward-looking peacemaking strategies so that the belligerents associate the end of fighting with a future benefit (opportunity to benefit from a post-violence order) rather than an immediate loss (the discontinuation of the conflict economy).

In one case, it has been possible to translate economic agendas into pragmatic consensus for engagement. In Sudan, oil has been a central focus of the economic agendas of both the government and the SPLM/A. High levels of armed violence in oil-producing regions prevented the government from fully benefiting

49 William Reno, 'War, markets, and the reconfiguration of West Africa's weak states', in Comparative Politics, Vol. 29, No. 4, 1997, p. 496.

50 Achim Wennmann, 'Getting armed groups to the table: peace processes, the political economy of conflict and the mediated state', in Third World Quarterly, Vol. 30, No. 6, 2009, pp. 1123-1138.

51 I. William Zartman, Ripe for Resolution: Conflict and Intervention in Africa, Oxford University Press, Oxford, 1985, pp. 232-236. 
from the revenue potential of the oil wealth because they undermined efforts to attract foreign investors. Some oil companies made the case to all belligerents that the end of fighting and a peace process was the best strategy to ensure sustainable oil production and benefits for all. One company even led informal talks making the case that 'oil represented an incentive for peace in so far as oil activities could not be pursued in a war context'. ${ }^{52}$

At the same time, oil disproportionately increased the revenue of the government, and thereby changed the military balance between the parties. Not being able to equalize these revenues in the long term, the SPLM/A decided that it had more to gain from negotiations, because it perceived that the continuation of the conflict would end in military defeat. The leader of the SPLM/A, John Garang, even remarked that 'the cost of continuing the war was felt by both sides to be much higher than the cost of stopping the war. So, we stopped the war. ${ }^{53}$ The government came to the conclusion that it could not stop the attacks by the SPLM/A indefinitely. Thus, there was a mutual interest in exploring negotiations.

The Sudan example highlights how economic agendas provided a framework for a tactically informed decision to shift the fighting from the battlefield to the negotiation table. In this case negotiations led to a wealth-sharing agreement that resulted in USD 5.4 billion being transferred to Southern Sudan between 2007 and 2009. ${ }^{54}$ However, the Agreement on Wealth Sharing (AWS) only covered what could be called the 'visible' part of Sudan's economy. It did not cover the various parallel or 'invisible' economies that are part of both northern and southern patronage politics related to the oil sector..$^{55}$

Managing these economic dimensions in a responsible manner is a significant challenge when engaging armed groups. Too much pressure on sensitive economic issues - such as financing structures, dealings with commercial actors, and actual levels of revenue - may antagonize armed groups and keep them from the negotiation table. In a sense, these issues may be more effectively handled outside a formal agreement. In the Darfur negotiations in April and May 2006, the final talks about the Darfur Peace Agreement were accompanied by intense informal talks between the parties about the price to pay for the bargain. They agreed on the creation of a compensation fund under the personal control of one of the Darfur negotiators. ${ }^{56}$

52 Christine Batruch, 'Oil and conflict: Lundin Petroleum's experience in Sudan', in Alyson J. K. Bailes and Isabel Frommelt (eds), Business and Security: Public-Private Sector Relationships in a New Security Environment, Oxford University Press, Oxford, 2004, pp. 159-160.

53 Voice of America 'Peace agreement will "lead to a new and prosperous Sudan" says rebel leader', 30 May 2004, available at: http://www.voanews.com/english/news/a-13-a-2004-05-30-11-1-67348442.html (last visited 5 November 2008).

54 A. Wennmann, above note 37, p. 82.

55 Achim Wennmann, Wealth sharing beyond 2011: economic issues in Sudan's north-south peace process, CCDP Working Paper 1, Graduate Institute of International and Development Studies, Geneva, 2009, p. 16.

56 Alex De Waal, Fixing the political marketplace: how can we make peace without functioning state institutions?, Fifteenth Christen Michelsen Lecture, Bergen, 15 October 2009, p. 8, available at: http:// www.cmi.no/file/?877 (last visited 14 October 2011). 
These examples indicate that transitions out of armed violence require a certain space for informal arrangements that allow the parties to manage complex internal negotiations and transform an armed group's military and political structures. If belligerents are expected to disarm and transform into a political party, the structures created to finance the conflict may become the foundation to enable this transition. As a result, those actors engaging armed groups must find a workable balance between the parties' requests for informality to manage their own internal transformation and external requests for transparency, accountability, and compensation.

Finding this balance is not easy and can only be answered with reference to specific cases. A strategy to bridge these competing demands may be to portray transparency issues as the outcome of a temporally defined transition process and not as an immediate demand. Insisting on transparency and accountability right from the beginning would be unrealistic if a mediator is intent on building a working relationship with targeted individuals; perhaps it may even jeopardize an entire peace process. Placing economic issues on the agenda means touching on the parties' financing structures, and this can be interpreted as an unacceptable constraint on their mobilization, and result in alienation from a nascent peace process.

\section{Conclusion}

The economic dimensions of armed groups should be approached with an open mind so that issues such as financing, costs, and economic agendas can be perceived as opportunities, and not necessarily as a problem for peace. Many aspects related to these economic dimensions are an undeniable fact in conflict areas, and are perceived as a concern by the policy or advocacy communities, especially owing to the humanitarian consequences of different methods of conflict financing. However, to treat the economic dimensions of armed groups as a politically unpalatable issue is unsustainable for fostering a lasting exit from armed conflict. The question therefore arises of how best to address the economic dimensions of armed groups in a nascent peace process.

A first proposition would be to avoid the use of labels such as 'warlord', 'criminal', 'smuggler', or 'drug trafficker' that are often used to characterize armed groups or their leaders. While they may be involved in activities that from an outsider's perspective are perceived as such, from an insider's perspective whatever an armed group is involved in would be described as a completely normal and legitimate affair. As far as mediation efforts are concerned, one should recall that it is not the task of a mediator or mediating institution to make judgement calls, and the use of the wrong label in the wrong circumstance can destroy years of relationship building. This is partly because of the loss of independence of the mediator that such judgements would imply, and because of the difficulty in finding the conclusive evidence to prove these labels right in messy, informationpoor, and rumour-rich civil war contexts. 
A second proposition would be to explore the opportunities deriving from transformative negotiations that structure incentives around the economic dimensions of armed groups. Such negotiations would find ways to bridge the demands for immediate change from international actors and the request for informality from armed groups to allow for internal transformations. They must also have a set of direction and rules that define the bounds of what is acceptable in a transition process, and what is not, as well as what sanctions apply for violating formal or informal agreements. Such transitions are necessarily fluid and composed of periodically renegotiated informal deals. They may also involve both the parties and external parties in accepting operating within the context of ambiguity. These may be the best of multiple bad options to transform war economies and armed groups, and may become the precursor to a more structured political process further down the line that reduces ambiguity and fluidity and increases the predictability of interactions.

By way of conclusion, it should also be mentioned that international policy against the financing of armed groups has fundamentally changed in the light of the international efforts to counter the financing of terrorism. ${ }^{57} \mathrm{~A}$ decade ago, initiatives against rebel financing focused mainly on coercive, legal approaches such as targeted sanctions on commodities, trade, travel, or bank accounts, as well as multi-stakeholder coalitions, such as the Kimberley Process against conflict diamonds. ${ }^{58}$ Efforts against terrorism added another layer onto these initiatives through the development of an unprecedented capacity of regulatory and financial institutions to monitor financial flows. ${ }^{59}$ According to one observer, 'one unintended consequence of the successful implementation of this financial regime was to force would-be terrorists to rely on local, low-cost, underground, and informal methods of financing' ${ }^{60}$

There are two implications following from this statement. The first is that, if the UNITA or Kosovo Government in Exile were to set up their respective diamond and diaspora financing mechanisms today, they would find that more difficult to do than a decade ago as they might be subjected to targeted sanctions. Thus, the financial regime created against the financing of terrorism can be used to disrupt the financing of armed groups that wish to start up or scale up activities. The terrorism-related financial monitoring infrastructure is therefore likely to affect the ways in which armed groups select their financing methods, transfer mechanisms, and means of capital storage, and may as a result influence the formation and evolution of these groups.

57 The following paragraphs have been inspired by a conversation with Thomas Biersteker and joint work on countering the financing of terrorism.

58 For more information on the Kimberley Process, see http://www.kimberleyprocess.com/home/index_ en.html (last visited 15 September 2011).

59 Thomas J. Biersteker and Sue E. Eckert, 'Introduction: the challenge of terrorist financing', in Thomas J. Biersteker and Sue E. Eckert (eds), Countering the Financing of Terrorism, Routledge, London, 2008, pp. 2-6.

60 Scott Atran, Talking to the Enemy: Faith, Brotherhood and the (Un)Making of Terrorists, HarperCollins, New York, pp. 207-208. 
The second implication is that the future financing for armed violence is likely to be sourced from the underground and informal space, thus underlining the need to explore new strategies to act in these spaces. A traditional, state-centric, response would be that these spaces are the domain of law enforcement and police agencies. They have both the infrastructure and the experience to monitor, investigate, and intervene in these contexts. An alternative, or complementary, route may lie in engaging armed groups in forward-looking transformative negotiations. Developing a better understanding of the evolution of armed groups, and issues relating to the financing, costs, and economic agendas, would be a starting point to embark on such war-to-peace transitions. 